Historic, Archive Document

Do not assume content reflects current scientific knowledge, policies, or practices. 

uncontrolled run-off of precipitation, with streams alternatine between rlood and drought stajes, and a steady decline or underground water supplies during critical periods. As a direct result of the pest abuse of our lands and our waste of their resources, many portions of the Ohio Valley have serious problems to face because of declining industries and business, decadent comunities, unemploynent, and alarming tax delinquency with virtual local bankruptcy in certain sections. This is a situation that affëts everyone - locally, regionally, and even nationally; it is a mortighe upon our future which must be redemed.

Timbor. The Central States, lying within or imodiately adjacent to the Ohio Talley, use more timber and forest products than does any other rewion, yet only about 50\% oi this is produced locally. The rest mis' be purchased and imported from other parts of the country at a eremendous cost. Curront treo growth in this region row equals only a litile more than half the anount of trood products produced locally (or $25 \%$ of the total consumpition), bccause our remaining second-growth forests are not beiig mans:ged conservatively for sustained production, nor ure thcy adequately protected from the excessive grazing of livestock, irom ropeated forest fires, or from continued exhalistive cutting. Yet with more than 70 million acres of present or potential forest lands in the central hardirook region - sick lands that are neither adapted to nor needed for agriculture - the oprortunitios ror profitable timber production are very great. Ihe many economic ard social beneits - to labor, industry, land owners, and to the public - which will result fron restoring tre productivity oî this vast forest area by sustained yield mansgement are very apparent.

Soj. $I$ and Water. In this region, as in many others, a protective as well as a productive forest cover for non-agricultural lands is essential. The Onio and its tributaries comprise one of the most important watersheds in the United States. On the rolling and hilly lands of the Ohio valley uncontrolled erosion and run-off of water lead to strcanclow and water conservation problems that are especially critical. Idle, barren, deforcsted lands ire usually severely eroded. Iacking a protcctivo cover of vefetation and leaf litter, the rapid run-off of water carries the top soil with it, and the eree bocomes iurther impoverished. Stream channels, reservoirs, and other engineering works becomo filled with eroded soil. Tecause of rapid run-orf, there is little absorption or storege of water in the scil, underground waters are not rovlarished, tho water table is lowored, wells and sprinis co dry at critical tines, and wator supplies become seriously reduced. At the same time, stream flo: fluctuates rapidly betweon high and low stages, causes tremendous damase from frequent rloods, and ondangers navigaiion. Ingineoringroblens of siream regulacion, flood prevention, and water consorvation becomo more difficult and costly to solve bocause of our past treatnent of the land surface of the watersheds. It is high time that agriculturists, engineers, and foresters coordinate their offorts for conservative land usa. When those areas adapted to arriculture are properly cultivetcd with due consideration for soil conservation, and when all non-agricultural lands are protected and nedo productive by thrifty forests properly managcd, tho entinecr's probleis of struarin low control and water conscrvotion will bo greaty simpliried, and the tremendous cost of their solution will be greatily lesscred. The tax-payer should be intorested. 
The erosion of severely gullied lands is very noticeable, but the average citizen does not appreciate the losses of soil and water that occur constarily from unprotected slopes subject to the less apparent but very destructive sheet erosion. Neither does he appreciate the protective influences of different kinds of cover. Data collected by the soil trow sion Experinent Station near Zanesville, Ohio, following tho very heary:. rainfall that occurred early in August of this year, aro very enlightening. The folloning sumarizes portions of an article that appeared in the Columbus Dispatch on Sundoy, August 11:

"It is expected that analysis will show a loss in excess of 20 tons of soil per acre for cultivated fiolds . . . Only 61\% of the rain falling upon the experimental plot in srass ras lost - - Wheat stubble assists in holding water on the farm land, a loss of $65 \%$ being measured for this rain... The plot in continuous corn losi $32 \%$... An experimental plot of bady eroded land lost $37 \%$ of the jater falling on it during the rocent storm - . Phe plot winich had practically all regctotion romovod lost $95 \%$. . . The roods plot has had little water loss and no soil loss since its establishment in October, 1933. Less thon $1 \%$ of approximately 50 inches of rainfall on this plot has beon lost in the form of run-or. This is a contrast to an averago $9 . \mathrm{n}-$ nual weter loss of. $25 \%$ from experimentel plots plantod to corn."

In further explanation of the mun-cif from lands vith different types of cover, Mr. J. H. Snyöer, Superintendent oi the soil Erosion station, wrote me as iollows: mith regard to the rains of August 7 and 10 , 1835, these figures have not all been compiled but I can Eive you a percentige of mu-off that occurred on our cultivated watershed, pasture ". watershed, and tho soods arces. On August 7 we had a rain of 2.63 inches, occurring in about eight hours. The percentage of run-off from the cultivated watershed was $54 \%$, from the pasture watershea $37 \%$, and from the woods area 1.8\%. On August 10 we had a rather intunse rain when 1.5 inches fell in twenty minutes, the first inch of rain coming in ten minutes. On the same plots mentioned above, the losses wore $47 \%, 28 \%$, and $2.8 \%$, respectively."

These data conform closely to the results of the work of Dr. John T. Auten of our Station, in his study oi the porosity and water absorptive capacity of the soils under forost cover compared with adjacent cleared lands. In spite of similar evidence available in all parts of the country where erosion and run-off studies are being conducted, there are $x$ arsons who still doubt that forests are of much importance in helping to solve erosion and streamilow problems

Recreation and Nild Life. Devastated lands and intermittent strcans do not contribute to the conservation of ish, game and wilf life, nor to the ievelopment of outdoor rocreation facilities. Game requires a suitable habitat with adoquate shclter and food; fish cannot thrive in mudily, polluted watcrs. The public seeling an outdoor playground is not attracted to an impoverished resion lackine in forcst and water resources: Their dovelopment for recreational use in cortain sections contributes directly to the solution of an important social problen - how to spend our leisure time - and adds greatly to regional wealth, increased business and employment.' In many parts of the country. providing outdoor recreation 
has bocome the leading business, and there is a demand for it everywere. This is but one more of the many phases of land use that might be mentioned in which sorestry has important contributions to make.

There need be no conflict between the use of forests for timber production, for watershed protection, for rocreational use, and for other purposes. inder carefully planned and skillfully applied multiple-use management, areas may be selected and developed for any or 0.11 of these services to the extent that they are needod locally. That this is so has been convincingly demonstrated on a large scale in the management of the National Forests by the U. S. Forest Service, and by other arencios with sinilar land use policies.

\section{The Conservation Program}

Within recent years wo have seen the beginning of a great expansion in the nation-wide program of conservation, designed to restorc and perpetuate the essentials of basic national wealth. This has krought to the Ohio Talley a great incrousc in effort to conserve forcsts and the resources of timber, water, soil, and wild life which forests produce or protect. Wilderness and non-agriculturel areas are being acquired for public forests, parks, game refuges, and for other purposes in the public interest. Conservancy districts are being developed within important river basins. Neq units of liational forests are being acquired in all of the Central states. Civilian Conservation Corps camps have boen established throughout the repion to undertake necessary and constructive work under the direction of the U. S. Forest Service and other federal and state conservetion organizations. The Soil Conservation Service of the Dopartment of Agriculture is at work to romody the serious erosion problem on the farm lands of this region. Both public and private agencies are cooporating to end forest devastation of privately-omed woodlands, and to bring about sustained timior production and operation, in contrast to the old "cut out and got out" practices which led to impoverishment and land abandonment in so many places. These and othor projects now under way indicate that the Nation is at last awakening to the necessity for conservation of natural resources.

\section{The Need for Bfore Rosearch}

This sudden expansion of conservation work, in a region where many agencies are now undertaking now projects on a large scale for the first time, carries with it a very greatly increased demand for lmowledge and inforration of all kinds. It is essential that those responsible for projects lonow the facts of the siturtion with which they are dealing, the best methods to use, and the results to be expected. Otherwise, costly mistakes or delays are inevitable, and in some instances they may oven prove fatal to the enterpriso.

In this region there is a generally acknowledged lack of infornation necessary to the successiul establishment, protection, and manarement of forests. The various factors of forest influences are only partly understood. It is most unfortunate that a comprehensive proeram of forest rosearch could not have preceded by several years the present expansion of forest land management in the Central States. Even now the forest research program is lagging seriously, and thero appears to bo little opportunity 
to correct this situation as long as a large part of the research work is necessarily continued as temporary projects financed by emergency funds of uncertain duration. Research requires the best offorts of welltrained specialists, working under carefully laid plans with definite objectives and freedom from unnecessary restrictions or intermptions; it cannot be carried on effectively as emergency work with untrained personnel, with sudden starts and stops, with no continuity and no assurance of permanency. In the failure to provide for an increase in research on a scale comparable to other lines of forestry work, a critical situation already exists. Those in charge of various projects are calling for information that is not now available, yet they must have it if their work is to be carried on successfully. The immeaiate expansion of forest rescarch in the Central states on a sound, permanent basis is highly imperative.

In conclusion, it may be said that an encouraging start has been made in this region to correct the serious land abuscs of the past, and to restore the replaceable natural resources that are so essential to future prosperity. Iovever, it should be realiz. C that this work has only begun, and if the necessary objectives are to be achieved it must bo allowred to progress steadily, without set-backs, for many years. Woak parts of the program must be strengthened, conflicting authority and duplication of offort must be eliminated, end the various phases of land utilization must be efficiently coordinated. To assure the success of this movement, every good citizen should becone intelligently interested, and should give his full support to it. Self-interest, as well as concern for his country, should persuade him to do this. It is a sound investment in America's future. 


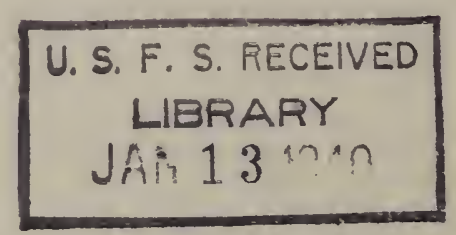

